\title{
EL TRATAMIENTO DE UN CORPUS DE ANGLICISMOS DE LA PRENSA MEXICANA DEL SIGLO XX EN LOS DICCIONARIOS DE LA RAE
}


Debido a la gran importancia adquirida por el inglés en el siglo pasado, la incorporación de anglicismos al resto de las lenguas se ha convertido en un fenómeno global. México, país colindante con los Estados Unidos de América, es uno de los países hispano-hablantes afectados por esta tendencia.

El objetivo de este trabajo es determinar el grado de admisión de un corpus de anglicismos encontrados en la prensa mexicana publicada durante siglo $\mathrm{xx}$ en las distintas ediciones del Diccionario de la lengua española, obra de referencia de la Real Academia Española y del Diccionario manual e ilustrado de la lengua española, resumen a la vez que suplemento de este. Se examinará en qué edición se admitieron por primera vez estos anglicismos, la información etimológica atribuida y las modificaciones gráficas sufridas, y se comparará esta información con la ofrecida en la $22^{\mathrm{a}}$ edición del diccionario con el fin de determinar si se han observado cambios en estos anglicismos a nivel gráfico, léxico o semántico.

Palabras Clave: anglicismos, siglo xx, etimología, diccionarios, Rae, prensa mexicana

Due to the importance acquired by English in the last century, the inclusion of Anglicisms in the rest of the languages has become a global phenomenon. Mexico, neighbouring country of the United States of America, is one of the Spanish-speaking countries affected by this influence.

This paper aims to determine the degree of admission of a corpus of Anglicisms found in the Mexican press published during the 20th century in the different diccionaries by the Spanish Royal Academy. The first date of admission of each Anglicism in the dictionary, the etymological origin attributed to them and the graphic modifications suffered by the Anglicisms will be examined. All this data will be contrasted with the information offered by the 22nd edition of the DRAE, in order to trace the changes occurred of all those words in a graphic, lexical and semantic level.

KeY wORDs: anglicisms, 20th century, etimology, dictionaries, mexican press, Spanish Royal Academy

RECEPCIÓN: 09/01/2015

ACEPTACIÓN: 19/05/2015 


\title{
EL TRATAMIENTO DE UN CORPUS DE ANGLICISMOS DE LA PRENSA MEXICANA DEL SIGLO XX EN LOS DICCIONARIOS DE LA RAE
}

\author{
María Vázquez Amador \\ Universidad de Cádiz
}

\section{Introducción}

El español es hoy en día una de las lenguas más importantes del mundo, no sólo por el gran número de hablantes, sino por su amplia extensión geográfica. Se habla principalmente en España e Hispanoamérica, aunque también en Guinea Ecuatorial, Filipinas e incluso en algunas zonas de Estados Unidos.

La lengua española en América es lengua oficial en dieciocho repúblicas independientes (México, Guatemala, Honduras, Nicaragua, El Salvador, Costa Rica, Cuba, República Dominicana, Panamá, Venezuela, Colombia, Ecuador, Perú, Bolivia, Chile, Argentina, Uruguay y Paraguay), en Puerto Rico, Estado asociado a Estados Unidos, y, asimismo, la lengua española es vehículo de comunicación entre la minoría de origen hispano en Estados Unidos (Sánchez Lobato 1994: 553). 
Con el fin de regular el uso correcto de la lengua española, a partir del siglo XVIII comenzaron a surgir organismos con esta finalidad. En 1713 se fundó la Real Academia Española en Madrid, en el siglo xix se inició la creación de las academias de la lengua en cada uno de los países hispanohablantes y durante el siglo xx se constituyó en México la Asociación de Academias de la Lengua Española (ASALE) en la que participan las 22 academias existentes en el mundo. La Real Academia Española ${ }^{1}$ se creó con el objetivo de "fijar las voces y vocablos de la lengua castellana en su mayor propiedad, elegancia y pureza”. En 1780 se editó el Diccionario de la lengua castellana y desde entonces se han publicado veintidós diccionarios dependiendo de las necesidades surgidas en cada época. Durante el siglo xviII aparecieron tres ediciones; en el siglo xIx fueron diez, entre las que destacan la edición de 1803, caracterizada por la admisión de numerosos neologismos científicos; y la de 1884, en la que se admiten diversas voces técnicas y del habla popular y comienzan a incluirse las etimologías el léxico procedente de otros países hispanohablantes. En el siglo xx se publicaron ocho, siendo la más relevante la de 1925, edición en que se registra un considerable aumento de americanismos. En el siglo xxi han sido publicadas dos ediciones, la de 2001 que incluye gran cantidad de voces del español de América y la de 2014.

Asimismo, la Real Academia Española ha publicado ediciones en 1927, 1950, 1985 y 1989 del Diccionario manual e ilustrado de la lengua española, "pieza clave en la historia

${ }^{1}$ Tomado de http://www.rae.es/la-institucion 
de la lexicografía española del siglo xx, que se desarrolló a la sombra del DRAE, pero que tuvo más influencia en la sociedad debido a su uso en las aulas, sobre todo en sus dos primeras ediciones (1927 y 1950)" (Garriga y Rodríguez, 2008).

A lo largo de la historia, la cultura y la lengua española han estado influidas por distintos pueblos como indica Rosenblat: "[...] ¿qué quiere decir pureza castellana? El castellano es un latín evolucionado que adoptó elementos ibéricos, visigóticos, árabes, griegos, franceses, italianos, ingleses y hasta indígenas de América" (1970: 1). Hoy en día, esta influencia proviene principalmente de la lengua inglesa y se traduce en la incorporación de anglicismos al español. El fenómeno del anglicismo ha sido ampliamente estudiado por muchos investigadores (Pratt, 1980; López Morales, 1987; Lorenzo, 1996; Rodríguez González, 1999; Rodríguez Segura, 1999; Gómez Capuz, 2000; Rodríguez Medina, 2000; Seco, 2000; Sáez Godoy, 2005; y Cruz-Cabanillas y Tejedor, 2012 y 2014, entre otros).

Nosotros entendemos por anglicismos las voces de procedencia inglesa que otras lenguas adoptan, normalmente para nombrar un concepto nuevo o por otra serie de causas lingüísticas como el uso de sinónimos y efectos estilísticos. En el momento en que los anglicismos se introducen en la lengua, su futuro es incierto, siendo un factor de suma importancia su frecuencia de uso, cuanto más se utilicen, mayor será la probabilidad de que se instalen en la lengua. Cuando estas voces permanecen en la lengua receptora pueden mantener la grafía inglesa (e.g. closet), transformarse para asimilarse a las reglas ortográficas de esta (e.g. beisbol, 
procedente de la voz inglesa baseball) y en el caso de los vocablos bimembres traducirse como calcos léxicos (teléfono celular, procedente de la voz inglesa cellphone). A nivel semántico pueden conservar el significado original con el que llegaron a la lengua española o pueden modificarlo con el paso del tiempo. Por el contrario, en otras ocasiones la vida de estos anglicismos es efímera y desaparecen por caer en desuso (e.g. buggy, un tipo de coche) o por ser sustituidos por vocablos autóctonos (e.g. browser sustituido por navegador) (Vázquez Amador, 2015).

Existen diversas clasificaciones de los anglicismos atendiendo a distintos criterios, como la necesidad de incorporación de estos a la lengua (Alfaro, 1948); su frecuencia de uso (Lope Blanch, 1986 y López Morales, 1987); y criterios lingüísticos (Medina López, 1996). La mayoría de las clasificaciones son formales (Pratt, 1980; Lorenzo, 1987; Gómez Capuz, 1998; y Rodríguez Segura, 1999), los autores se basan en las características ortográficas de los anglicismos y sus diferencias con las reglas de la lengua receptora para describirlos. En este estudio se catalogarán los anglicismos desde un punto de vista formal basándonos en la tipología de Lorenzo (1987) y Pratt (1980), que clasifican los anglicismos según su grado de adaptación a la lengua española. Se distinguirá entre anglicismos con apariencia inglesa, parcialmente inglesa y española.

- Los anglicismos de apariencia inglesa se dividen en anglicismos crudos, gráficamente iguales a la voz de procedencia (e.g. closet); falsos anglicismos, palabras que no existen en inglés a pesar de estar formadas por lexías inglesas (e.g. footing); y anglicismos hiperca- 
racterizados, aquellas voces que parecen más inglesas que la grafía original (e.g. smocking procedente de la voz inglesa smoking).

- Los anglicismos con apariencia parcialmente inglesa son vocablos cuya grafía aún mantiene elementos extranjeros normalmente porque se ha adaptado la grafía a la pronunciación inglesa (e.g. zum procedente de la voz inglesa zoom).

- Dentro de los anglicismos con apariencia española están los anglicismos ya totalmente adaptados a la ortografía española (bife procedente de la voz inglesa beef); los calcos léxicos, vocablos bimembres traducidos del inglés (e.g. cabeza rapada procedente de skin head); y los préstamos semánticos, aquellas palabras españolas a las que se les añade una acepción por influencia de una palabra inglesa (e.g. conductor, haciendo referencia a un presentador de televisión).

El uso de los anglicismos en los medios de comunicación propicia que los lectores también los utilicen, debido al gran poder de difusión que tiene la prensa (Perdiguero, 2003). La prensa es un medio de comunicación escrita que proporciona información sobre las noticias a nivel nacional e internacional y trata temas de diversa índole. La prensa refleja la vida de la sociedad y, consecuentemente, el lenguaje que esta utiliza. Según Alvar Ezquerra, a través del lenguaje periodístico se puede conocer no sólo la incorporación de nuevas palabras sino la actitud de la lengua ante estas.

El lenguaje periodístico escrito es una rica fuente no sólo de ejemplos con los que ilustrar los procesos de formación e incorporación de 
palabras en la lengua, sino también para tomar el pulso de la vitalidad de ésta, para conocer la capacidad que posee para soportar la llegada de extranjerismos, y su potencialidad creadora, que hacen que siga viva, produciendo novedades a cada instante (1998: 40).

Una vez que los anglicismos se asientan en la lengua y comienzan a ser utilizados por el hablante, el siguiente paso en su proceso de asimilación a la lengua receptora es la inclusión de estos en los diccionarios. Una de las decisiones que tienen que tomar los lexicógrafos es el tratamiento que se les dará, como indica Balterio:

An important decision in dictionary design is the treatment given to borrowings or foreign words, that is, whether they should be included in cases of widespread usage (following a descriptive perspective), or rejected because the lexicographer considers that they are undesirable (from a prescriptive approach) (2011: 277).

Según Haensch y Omeñaga los diccionarios normativos son más recelosos con la admisión de préstamos lingüísticos que los descriptivos.

Los diccionarios normativos parten de un determinado ideal de lengua considerado como norma y rechazan, por lo general, las unidades léxicas contrarias a la norma preceptiva, que suele ser la de las Academias de la Lengua. Por eso, es lógico que un diccionario normativo (por ej., un diccionario académico o escolar) adopte una actitud expectante ante los neologismos y los extranjerismos (2004: $62)$. 
El diccionario de la Real Academia Española (DRAE) ${ }^{2}$ tiene un carácter normativo, como se indica en la presentación de la 22a edición. El criterio de la Academia para la aceptación de préstamos lingüísticos es el grado de necesidad de su incorporación, la falta de equivalente en español o la imposibilidad de expresar ese concepto o idea mediante una palabra española. La RAE distingue entre los extranjerismos innecesarios o superfluos, aquellos que tienen equivalente español, y los necesarios o muy extendidos, aquellos que no tienen equivalente español o cuyo empleo está arraigado o muy extendido. Con respecto a la grafía de los préstamos, la Academia tiene dos criterios: el mantenimiento de la grafía y pronunciación originaria, en el caso de aquellos extranjerismos asentados en el uso internacional, o de la grafía originaria (se mantiene la grafía original, pero adapta la pronunciación y la acentuación a las reglas de la lengua española) o la adaptación de la pronunciación (se mantiene la pronunciación de la voz extranjera, y se adapta la forma extranjera al sistema gráfico del español) intentando que haya coherencia entre la forma gráfica y la pronunciación.

Son muchos los autores que han investigado la aceptación de los préstamos lingüísticos en los diccionarios académicos. Vives Coll (1989) estudia la función reguladora del DRAE en los anglicismos económicos en las ediciones de 1970 y 1984; Domínguez Mejías (2002) analiza diversos aspectos de los anglicismos admitidos en el DRAE (2001); Barcia (2005) en la presentación del Diccionario panhispánico de dudas explica el tratamiento de los neologismos y extran-

${ }^{2}$ Consultado en: http://buscon.rae.es/draeI/ 
jerismos en este diccionario; Alcoba (2006) intenta determinar si el uso y la frecuencia de ciertos anglicismos en la prensa se corresponde con su aceptación en el DRAE; Aleza Izquierdo (2008) lleva a cabo un estudio sobre la presencia de voces de origen extranjero en el Diccionario panhispánico de dudas (DPD); Sánchez Martín (2011) analiza los cambios en los artículos que se refieren a los préstamos del inglés no adaptados en el DRAE (2001); Giménez Folqués (2010) examina la presencia de extranjerismos en el DRAE y el DPD; y Degerstedt (2013) realiza un estudio comparativo entre los préstamos recogidos en el Banco de neologismos de OBNEO y las nuevas entradas en el DRAE.

El objetivo que se persigue en este trabajo es determinar la presencia de un corpus de anglicismos encontrados en la prensa mexicana del siglo xx en los distintos diccionarios de la Academia. Se detallará la primera edición en la que se admitieron los anglicismos, la información etimológica, el grado de adaptación gráfica de estos a la lengua española y se compararán estos datos con la información que se refleja en la $22^{\text {a }}$ edición del diccionario.

\section{Metodología}

Para llevar a cabo este estudio se utilizó un corpus de anglicismos extraídos del diario Excélsior, uno de los periódicos más influyentes en México durante el siglo xx. Se leyó un ejemplar completo por año desde la primera fecha de publicación del periódico en 1917 hasta 1999, es decir, un total de 82 ejemplares, y se anotaron los anglicismos encontrados. Los ejemplares del diario Excélsior se encuentran disponibles 
en microfilm en la Hemeroteca Nacional de México. Esta Hemeroteca, una magnífica herramienta para la investigación, tiene su origen en 1944 cuando el crecimiento de la colección de periódicos y revistas de la Biblioteca Nacional llevó a su creación.

El corpus está formado por 922 anglicismos procedentes de 737 voces inglesas, es decir, aparecieron anglicismos que tenían la misma voz de origen y estaban en distintos estadios de asimilación a la lengua española. Se buscó cada uno de los anglicismos en los diccionarios con el objetivo de recabar información sobre su situación: la grafía con la que se registraban en el diccionario, la edición en que aparecían por primera vez; y la información etimológica ( $\mathrm{voz}$ inglesa, anglicismo, procedente "del inglés", o sin información etimológica) que se incluía sobre el anglicismo. Dicha búsqueda se realizó tanto con la misma grafía con la que se encontraron en prensa los anglicismos, como con grafías más adaptadas a la lengua española. Por ejemplo, entre los anglicismos encontrados en el periódico estaba business, que se registró en el diccionario como bisnes, manteniendo la pronunciación de la voz inglesa, y adaptándola al sistema gráfico del español. Para ello se utilizó el Nuevo tesoro lexicográfico de la lengua española en su versión en línea, una herramienta que permite consultar todas las ediciones de los diccionarios de la RAE desde 1726. El Nuevo tesoro lexicográfico de la lengua española (NTLLE) es un diccionario de diccionarios y contiene todo el léxico de la lengua española desde el siglo xv hasta el xx. Asimismo se consultó la edición DRAE (2001) a través de su edición electrónica. De esta manera se pudo comparar si la situación actual del an- 
glicismo había cambiado en cuanto a la grafía, información etimológica o definición con respecto a ediciones anteriores del diccionario.

\section{Análisis de datos}

Del total de 922 anglicismos extraídos del corpus, se aceptaron en el diccionario un total de 345 voces. En ediciones anteriores se registraron un total de 259 anglicismos, de los cuales 228 voces siguen vigentes en la $22^{\text {a }}$ edición del DRAE (2001). Esta edición recoge 312 de los anglicismos, 84 de los cuales no habían sido aceptados con anterioridad, es decir, eran nuevas incorporaciones.

\section{Anglicismos admitidos en las ediciones del siglo XIX}

Los anglicismos admitidos en las ediciones del siglo xIX son veintidós. En cuanto a la tipología formal de estos, como puede observarse en el gráfico 1, casi el 60\% de los anglicismos registrados en el diccionario estaban totalmente asimilados a la lengua española, algo más del 30\% eran anglicismos crudos, gráficamente igual a la voz inglesa de la que procedían y tan solo un pequeño porcentaje estaba formado por anglicismos de apariencia parcialmente inglesa y calcos léxicos. 
Gráfico 1. Tipología de los anglicismos admitidos en las ediciones del siglo XIX

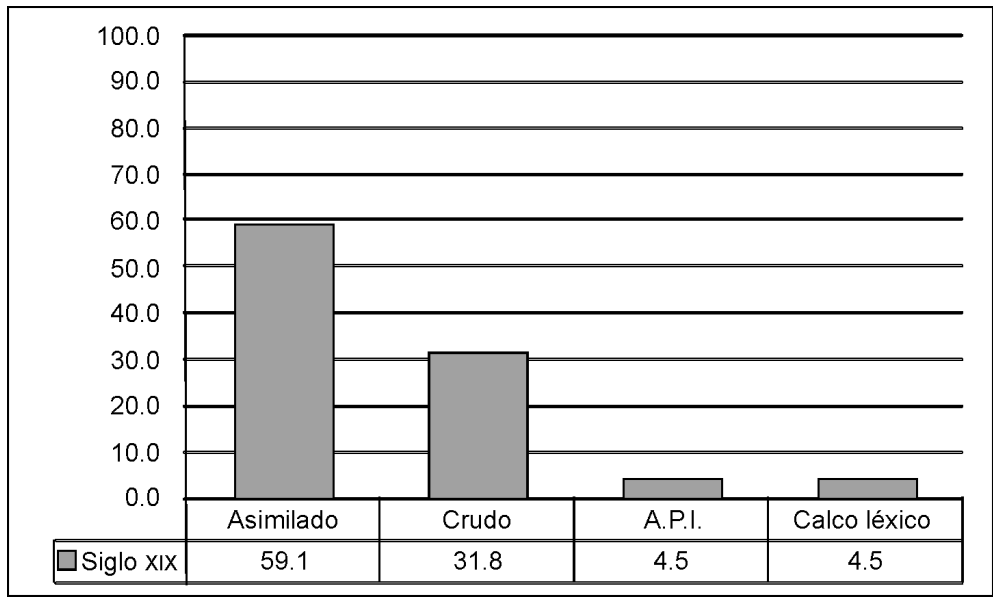

El diccionario acepta trece anglicismos ya totalmente asimilados al español. Cuatro fueron registrados sin alusión a su origen extranjero, entre otros yarda y yute; uno de ellos era un neologismo creado con lexías clásicas y se definía como procedente "del griego" (telegrama); otros dos provenían de nombres propios, el anglicismo linchar, procedente de "Lynch", y maltusiano de "Maltus"; túnel como voz de uso reciente; y los cinco restantes como procedentes "del inglés" (e.g. hurra y dril). Todos estos anglicismos siguen vigentes en la $22^{\text {a }}$ edición del diccionario con la misma grafía que en las ediciones anteriores, aunque con ciertos cambios en la información etimológica. En la mayor parte de ellos se admite el origen inglés de las voces, excepto en telegrama y maltusiano.

Se encontraron siete anglicismos crudos, casi todos definidos como procedentes "del inglés" (cheque, rifle y revolver) o usados "en Inglaterra" (lord y yacht), uno de ellos, club, sin 
alusión a su origen extranjero y el anglicismo wagon, que redirecciona a “vagón” admitido también en 1869. Todos están aceptados en la 22a edición como voces procedentes "del inglés". Dos de ellos se asimilan a la ortografía española, yacht como "yate" desde 1884 y wagon como "vagón" desde 1869. El resto mantiene su grafía original, que curiosamente no desentona con la española, revólver, cheque, rifle y club, con la excepción del anglicismo lord, que termina con la distribución inaceptable "rd".

Solo se registró un anglicismo de apariencia parcialmente inglesa con la grafía adaptada a la pronunciación inglesa, rosbif aceptado desde 1884 como procedente "del inglés" y vigente con el mismo origen y grafía en la $22^{\text {a }}$ edición. También se aceptó un calco léxico, guardacostas, definido como voz usada "en América", aunque ya en la 22a edición se admite como voz autóctona.

Los anglicismos admitidos en las ediciones del siglo XIX pertenecen a distintas áreas temáticas: alimentación (ron), economía (cheque), entretenimiento $(c l u b)$, voces generales (hurra), tecnología (telegrama), moda (dril), política y conflictos (linchar), sociedad (lord) y transporte (túnel), siendo los más numerosos los vinculados al transporte y las voces generales.

Con respecto al significado de los anglicismos, todos han mantenido una definición similar en las sucesivas ediciones del diccionario, excepto dos de ellos que han sufrido una ampliación en su significado: el anglicismo club en las primeras apariciones estaba restringido a un contexto político (Junta de individuos de alguna sociedad política clandestina) y en la $22^{\text {a }}$ edición se añaden dos acepciones más: 
1. Sociedad fundada por un grupo de personas con intereses comunes y dedicada a actividades de distinta especie, principalmente recreativas, deportivas o culturales.

2. m. Lugar donde se reúnen los miembros de estas sociedades. Va al club todos los domingos.

3. m. Junta de individuos que se constituían en sociedad política, a veces clandestina.

El anglicismo clíper en un principio hacía alusión a un tipo de embarcación (Buque de vela muy fino y muy velero) y en la $22^{a}$ edición añade una acepción relacionada con el transporte aéreo.

1. $\mathrm{m}$. Buque de vela, fino, ligero y muy resistente.

2. m. Avión grande para el transporte transatlántico de pasajeros.

En el cuadro 1 se muestra el número de anglicismos encontrados en cada una de las ediciones, destacando el alto número de anglicismos registrados en la de 1884, edición en la que, como se comentó en apartados anteriores, ya se admiten diversas voces técnicas y se incluye léxico procedente de otros países hispanohablantes.

Cuadro 1. Anglicismos registrados en lasediciones delsiglo XIX

\begin{tabular}{|c|c|}
\hline Fecha & Anglicismos \\
\hline 1803 & 2 \\
\hline 1832 & 1 \\
\hline 1837 & 1 \\
\hline 1869 & 4 \\
\hline 1884 & 9 \\
\hline 1889 & 1 \\
\hline 1899 & 4 \\
\hline
\end{tabular}




\section{Anglicismos admitidos en las ediciones del siglo $\mathrm{xx}$}

Es sin duda en las ediciones del siglo xx cuando el diccionario acepta un número más alto de anglicismos, con un total de 237 nuevas voces. En cuanto a la tipología de estos anglicismos, más de la mitad de estos eran crudos, gráficamente iguales a la voz original, aunque se registró un número bastante significativo de anglicismos totalmente asimilados a la lengua española y un grupo considerable de calcos léxicos y de anglicismos de apariencia parcialmente inglesa. Asimismo, se aceptaron en el diccionario un pequeño grupo de préstamos semánticos, voces españolas que por influencia inglesa añadían una acepción nueva a su significado y algún falso anglicismo. Todos estos datos se muestran gráficamente a continuación.

Gráfico 2. Tipología de los anglicismos admitidos en las ediciones del siglo $\mathrm{xx}$

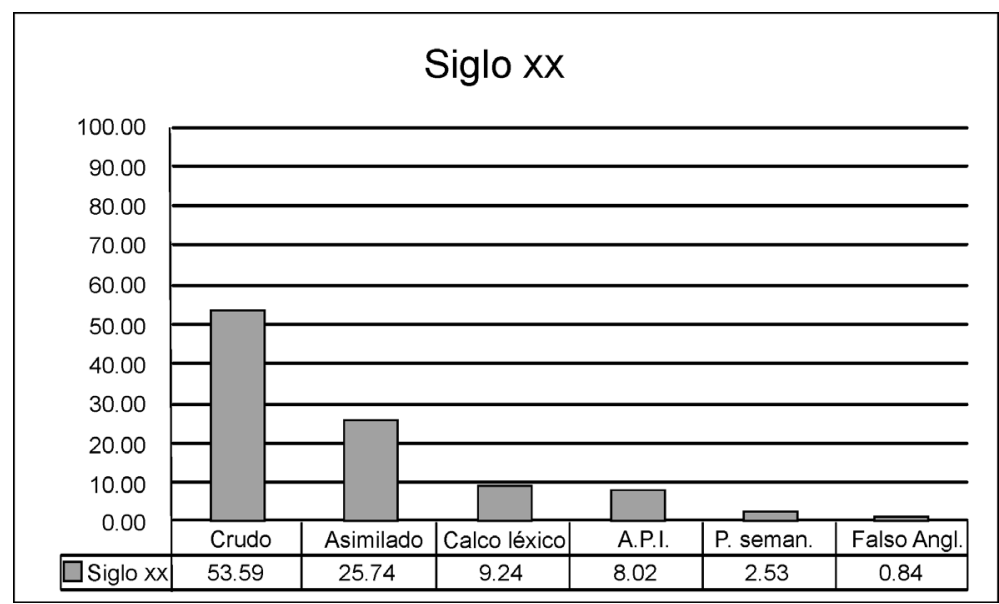


Es llamativo el alto número de anglicismos crudos como boom, closet y dumping que fueron aceptados en las ediciones del siglo xx con un total de 127 voces. Estos anglicismos presentaban diferentes orígenes etimológicos, normalmente haciendo alusión a su origen inglés como "anglicismo" (e.g. cróquet y match), procedentes "del inglés" (e.g. bill, clip y closet), usados "en América/Inglaterra" (hippy y miss) y sobre todo como "voz inglesa", ochenta y un anglicismos fueron definidos así, entre otros side-car, bungalow, off-side y flash. Siete anglicismos crudos remitían al anglicismo asimilado ya vigente en el diccionario (e.g. bikini a "biquini", reporter a "reportero"); tres eran nombres propios (e.g. charleston y $w a t t$ ); y diecisiete no presentaban información etimológica sobre su origen inglés y se caracterizaban en general por tener grafías bastante aceptables dentro del español, como tornado, polo, cinema o video, aunque algunos sí tenían grafías o combinaciones no aceptables como iceberg, ring y western.

De estos 127 anglicismos crudos, hay veintiséis que ya no están vigentes en la $22^{\mathrm{a}}$ edición, destacan sobre todo los admitidos en las últimas ediciones del diccionario, a pesar de ser algunos de ellos bastante conocidos como scout, showman y pub y dos de ellos incluso después de haber sufrido adaptaciones gráficas en ediciones anteriores (bulldog pasó a "buldog" y off-side a "orsay"). El resto de los anglicismos crudos siguen vigentes en la $22^{\mathrm{a}}$ edición, curiosamente la mayor parte de ellos con la misma grafía original. Tan solo trece se registran con una grafía más españolizada (e.g. nylon es aceptado como "nailon" y smog como "esmog"). Con respecto al origen etimológico atribuido a los anglicismos en esta edición, en la mayoría de los casos el diccio- 
nario admite el origen inglés del anglicismo, definiéndolos como "voz inglesa" o como procedente "del inglés". Aquellos anglicismos que provenían de nombres propios mantienen ese origen, al igual que los que remitían a un anglicismo más asimilado. En cuanto a los diecisiete sin información etimológica tan solo siete mantienen ese origen, como $d u$ plex y módem, voces formadas por grafías grecolatinas, el resto son reconocidos como voces inglesas o procedentes del inglés. Como dato curioso, dos anglicismos que eran reconocidos con anterioridad como "voz inglesa", party y sparring, en la actualidad no se registra su procedencia inglesa, a pesar de tener grafías que evidencian su origen anglófono. La mitad de los anglicismos registrados como "voz inglesa" en anteriores ediciones mantienen este origen en la 22 a edición, entre otros boom, ferry y short, y la otra mitad se registra como procedentes "del inglés". Todos se caracterizan por tener grafías o combinaciones inaceptables en español y no se aprecian grandes diferencias entre ambos grupos a nivel gráfico que dé lugar a la distinta denominación etimológica.

Se encontraron 61 anglicismos ya asimilados a la lengua española, como trolebús, procedente de la voz inglesa trolley bus y culi de coolie. Aunque se registraron diversos orígenes etimológicos, priman los anglicismos sin marca de extranjerismo y los definidos como procedentes “del inglés”. De los veintiséis anglicismos en que no había constancia del origen inglés, entre otros boicotear, driblar o cachar, muchos coinciden en ser voces creadas por derivación de un anglicismo, como filmación y filmar, procedentes de film o boxístico y boxeo, procedentes de la voz inglesa boxing. Las veintitrés voces definidas como procedentes "del inglés", entre otras 
champú, estandar y misil son anglicismos que aunque con grafías españolizadas, estaban directamente exportados del inglés, es decir, no estaban creados por derivación de un anglicismo. El resto de los anglicismos asimilados se definen como usados "en América” (lonchería y suéter), como "anglicismo" (picle), procedentes de nombres propios (e.g. rímel) o remitían a otro anglicismo (voleibol remite a "balonvolea"). Seis de estas voces ya totalmente adaptadas al español habían sido aceptadas en ediciones anteriores del diccionario con grafías crudas, bafle como baffle en 1983, bisté como bistec en 1925, filme como film en 1992, folclore como folklore en 1925, líder como leader en 1927 y guisqui como whisky en 1984. En la 22a edición tan solo tres de los anglicismos asimilados no están vigentes, lonchería, picle y vitáfono, los demás mantienen la misma grafía, excepto el anglicismo ladi, que en esta edición pasa a tener la grafía original inglesa lady. La mayoría son definidos como voces procedentes "del inglés". Se especifica que el anglicismo bife es usado en algunos países latinoamericanos (Arg., Chile, Par., Perú y Ur.), rimel y boicotear provienen de nombres propios y bisté remite a bistec. Diez de ellos siguen apareciendo sin información etimológica, misil, boxeo, boxístico, budinera, filmación, filmar, laborista, chutar, disquete, y tenista. Muchas de estas voces son palabras formadas por derivación de un anglicismo.

Los veintidós calcos léxicos como minifalda y microondas admitidos durante las ediciones del siglo xx no ofrecen información etimológica, con la excepción de hidroavión, aceptado con origen griego, marcapasos, como voz procedente "del inglés" y rascacielos, como "neologismo". En la 22a edición tanto hidroavión como rascacielos son registradas sin 
información etimológica, marcapasos como calco del inglés, al igual que balompié y aerolínea, y supermercado como procedentes "del inglés". El resto de los calcos léxicos mantienen el mismo origen que en ediciones anteriores y no se registran cambios gráficos ni semánticos.

Se encontraron diecinueve anglicismos con apariencia parcialmente inglesa, normalmente con grafías que imitaban la pronunciación inglesa. Estas voces tenían combinaciones y grafías no aceptables en lengua española como terminaciones finales en "-t", “-c" y “-m” o iniciales en "s-", uso de las grafías " $k$ " $y$ " $x$ " y combinaciones consonánticas como "ngs", "tb" y "ct". Diez de estos anglicismos eran admitidos en el diccionario como palabras procedentes "del inglés" o "voz inglesa", entre otros, aeróbic y colcrem. Crac fue registrado como "barbarismo", folclor remite al anglicismo crudo "folklore" y bloc al asimilado "bloque". Seis de ellos no presentan origen etimológico: gangsterismo, coctel, coctelera, futbol, futbolista y kilovatio. En la 22a edición todos siguen vigentes menos colcrem, y mantienen la misma grafía, excepto gangsterismo, y snobismo, aceptados como "gansterismo" y "esnobismo", y críquet que es registrado con la voz original inglesa cricket. Asimismo se aceptan dos grafías en el caso de bistec, también registrado como "bisté" desde 1983 y folclor, también admitido como "folclore". La mayor parte de estos anglicismos se definen como voces procedentes "del inglés" y el diccionario también especifica que los anglicismos nocaut, básquet y basquetbol se usan en América. Otros seis anglicismos siguen sin marca de extranjerismo, bloc, coctelera, futbolista, kilovatio, gansterismo y esnobismo y son en su mayoría palabras formadas por derivación de un anglicismo. 
Asimismo se encontraron en estas ediciones seis préstamos semánticos, voces españolas que adquirían una nueva acepción por contagio de una voz inglesa con grafía similar: reportar, elevador, condominio, extra, metro y terminal, todos vigentes en la $22^{\text {a }}$ edición. Se registraron dos falsos anglicismos, voces que parecen inglesas pero no existen en esta lengua, sportman y footing. El anglicismo sportman, aceptado en 1927 como voz inglesa y como sportsman en la edición de 1950 ya no está vigente en la 22a edición, y la voz footing, registrada sin marca de extranjerismo en $1984 \mathrm{y}$ como procedente del francés en la 22a edición.

Los anglicismos admitidos en los diccionarios académicos del siglo xx se adscribían a las áreas temáticas de gastronomía (sándwich y whisky), alojamiento (closet y rascacielo), deporte (piolet y surf), economía (dumping y trust), entretenimiento (puzzle y hobby), voces generales (autoservicio y detective), informática y tecnología (robot y switch), mascotas (pedigrí y foxterrier), moda (panty y smoking), música (pop y underground), política y conflictos (bunker y laborista), sociedad (party y snob) y transporte (trailer y charter), siendo más numerosos los anglicismos relacionados con el deporte, el entretenimiento y las voces generales.

A nivel semántico, la mayor parte de los anglicismos aceptados en las distintas ediciones del siglo xx conservan su significado original, aunque en algunas definiciones se observa una ampliación en el significado, como el anglicismo boom, que está limitado al plano económico en las ediciones de 1983 y 1989 (Máximo en la evolución del ciclo económico, cuando la economía está escasamente desocupada) y adquiere un significado más general en la actual (Éxito 
o auge repentino de algo, especialmente de un libro); handicap está restringido en las primeras definiciones de 1927 y 1950 al mundo deportivo, concretamente la hípica (Ventaja, partido y especialmente carrera en que uno o más caballos obtienen una ventaja en tiempo, distancia o peso para igualar la partida) aunque por extensión amplía su significado en ediciones posteriores como "Circunstancia desfavorable, desventaja"; al igual que récord, definido como "anglicismo por azaña deportiva que excede a las hechas anteriormente en el mismo género", mientras que en el DRAE actual se añade una acepción con un significado más general.

1.m. marca ( $\mid$ mejor resultado en el ejercicio de un deporte).

2. m. Resultado máximo o mínimo en otras actividades.

En otras definiciones se observaron puntualizaciones como el anglicismo clown que en las primeras ediciones de 1927 y 1950 era un sinónimo de payaso, mientras en la actual se define como "Payaso de circo, y especialmente el que, con aires de afectación y seriedad, forma pareja con el augusto", o cambios de significado, como miss, que ha pasado de ser el nombre dado a las señoritas en Inglaterra en 1927 a "Ganadora de un concurso de belleza" en la 22a edición; raid, que se definía en 1927 como "Recorrido o expedición", mientras que la definición actual está relacionada con el deporte, "Prueba deportiva en la que los participantes miden su resistencia y la de los vehículos o animales con los que participan recorriendo largas distancias", o el mundo militar, "Incursión militar, generalmente aérea"; sport, considerado un sinónimo de deporte en 1927, mientras que hoy en día hace referencia a un estilo de ropa informal. 
En el cuadro 2 se muestra el número de anglicismos admitidos por primera vez en las distintas ediciones del siglo xx. Llama la atención el alto número de anglicismos registrados en 1927, la primera edición del Diccionario manual e ilustrado de la lengua española y en los tomos publicados en 1984 y1985.

Cuadro 2. Anglicismos registrados en las ediciones del siglo $\mathrm{xx}$

\begin{tabular}{|c|c|}
\hline Fecha & Anglicismos \\
\hline 1914 & 3 \\
\hline 1925 & 8 \\
\hline 1927 & 54 \\
\hline 1936 & 3 \\
\hline 1947 & 2 \\
\hline 1950 & 2 \\
\hline 1956 & 3 \\
\hline 1970 & 28 \\
\hline 1983 & 17 \\
\hline 1984 & 45 \\
\hline 1985 & 45 \\
\hline 1989 & 7 \\
\hline 1992 & 20 \\
\hline
\end{tabular}

\section{Anglicismos admitidos en la edición del siglo XXI}

Asimismo, se encontraron 84 anglicismos que a pesar de no haberse registrado en ediciones anteriores del DRAE, sí se admiten en la $22^{\text {a }}$ edición. En cuanto a la tipología de estos 
anglicismos, como se muestra en el gráfico 3, los porcentajes encontrados son similares a los resultados obtenidos en los anglicismos admitidos en los diccionarios durante el siglo $\mathrm{xx}$. Priman los anglicismos crudos con casi un 60\%, seguidos por los anglicismos totalmente asimilados que representan casi el 20\%. Se halló un porcentaje similar de calcos léxicos y anglicismos con apariencia parcialmente inglesa y el número de préstamos semánticos no era demasiado elevado.

Gráfico 3. Tipología de los anglicismos admitidos en las ediciones del siglo XxI

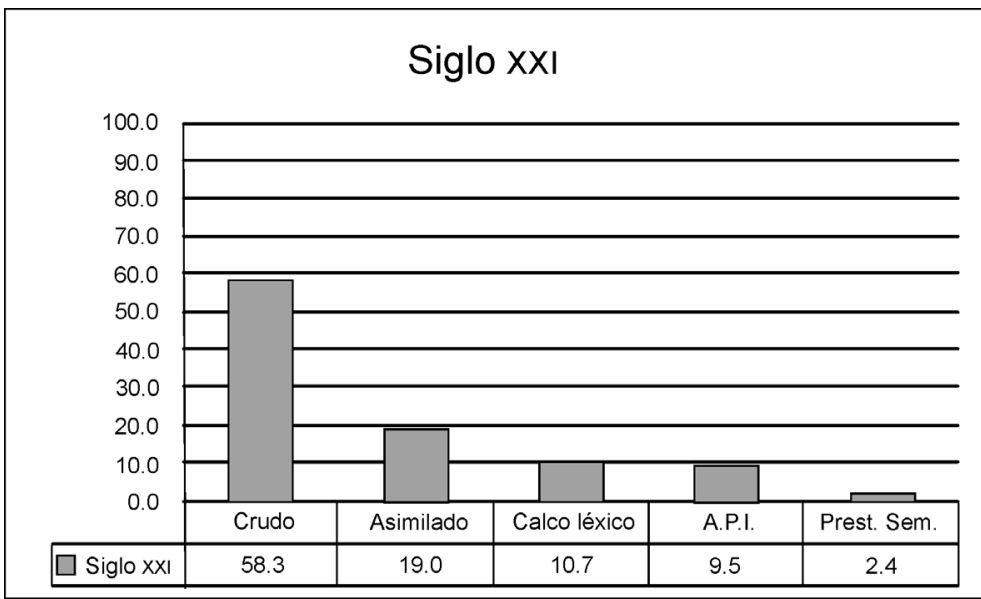

El grueso de los anglicismos encontrados son crudos y en casi todos ellos el diccionario hace referencia a su procedencia inglesa. Veintiséis anglicismos se definen como voces inglesas, entre otros hardware, sex-appeal y mass media y quince de ellos como procedentes "del inglés" (e.g. gag, toner y kit). Un pequeño grupo de seis anglicismos crudos 
se registra sin marca de extranjerismo como antivirus, glamour, internet y crayón. De los dieciséis de los anglicismos totalmente adaptados al español como bisnes, rostizado (en el diccionario en infinitivo, rostizar) y beisbolista, siete se definen como procedentes "del inglés", entre otros esprínter y jaibol, en tres de ellos se especifica que son usados en América (panqueque), en El Salvador, Honduras y México (rostizar) y en México (elevadorista), mientras los seis restantes se registran sin información etimológica, coincidiendo en su mayoría en ser palabras formadas por derivación de un anglicismo como glamuroso, lideresa o roquero.

Se registran diez calcos léxicos en la $22^{\text {a }}$ edición del diccionario, la mayor parte de ellos sin alusión a su origen, excepto ovni, aceptado como calco del inglés y toalla sanitaria (en inglés sanitary towel), como voz usada en El Salvador y Venezuela. Ocho de los anglicismos aceptados en esta edición tenían apariencia parcialmente inglesa, es decir, no eran iguales a las voces originales de procedencia, pero aún mantenían elementos extranjeros en sus grafías. Friki, yeyé, picop, estent y zum son aceptados como procedentes "del inglés"; y clic, jazzista y waterpolista sin marca de extranjerismo. Asimismo se registraron dos préstamos semánticos, computación y comercial, en cuyas definiciones se especifica que son voces usadas en América.

Los anglicismos admitidos en esta $22^{\text {a }}$ edición se relacionaban con las áreas temáticas de alojamiento (jacuzzi y living), gastronomía (curry y ginger-ale), deporte (caddie y green), economía (bisnes), entretenimiento (best seller y fanzine), voces generales (spanglish y kit), informática y tecnología (hardware y software), moda (blazer y look), música 
(dancing y reggae), política y conflictos (estado de bienestar), sociedad (jet set) y transporte (scooter), siendo más numerosos los anglicismos vinculados a la música, la informática y la tecnología y las voces generales.

\section{Anglicismos no admitidos en los diccionarios de la RAE}

El número de anglicismos localizados en el periódico Excélsior que no fue registrado en ninguna de las ediciones del DRAE con o sin cambios de grafía es muy significativo, 503 anglicismos, que equivalen a más de la mitad de las 922 voces registradas en el corpus utilizado para el estudio. Aunque se encontraron anglicismos de distintos tipos, la mayor parte de ellos, casi el 80\% eran crudos. Estos anglicismos se adscribían a distintas áreas temáticas, gastronomía, alojamiento, deportes, economía, entretenimiento, voces generales, informática y tecnología, mascotas, moda, música, política y conflictos, sociedad y transportes. Llama poderosamente la atención el altísimo número de voces deportivas que no han sido admitidas en el diccionario, especialmente las relacionadas con el beisbol, el rugby y las voces deportivas generales.

Entre los anglicismos no admitidos en el DRAE se encontraban algunos bastante conocidos como break dance, country, funk, go-go, heavy metal, playboy, thriller y walkietalkie; otros que habían sido sustituidos por voces españolas como browser por navegador, cornflakes por cereales, desktop por ordenador de sobremesa, goalkeeper por guardameta, hotdog por perrito caliente, printer por impresora 
y skinhead por cabeza rapada. Otro grupo de anglicismos eran más específicos o técnicos, como backfield, framework, gigabyte, RAM y setpoint. También se encontraron en prensa una serie de anglicismos que hacían referencia a voces que ya existían en el léxico español y no eran por tanto necesarias, por ejemplo high school, instituto de secundaria, highway, autopista, jeans, vaqueros, living room, sala de estar y shopping, compras.

\section{Conclusiones}

Ya desde principios del siglo xx la influencia del inglés sobre el español hablado en México queda patente a través de los anglicismos localizados en los distintos ejemplares leídos del diario mexicano Excélsior. Estos anglicismos son reflejo de los sucesos políticos, sociales y tecnológicos acontecidos durante este siglo.

El porcentaje de anglicismos admitidos en las distintas ediciones del diccionario de la Academia no es demasiado elevado, tan solo un $28.5 \%$ de los anglicismos extraídos del corpus de periódicos del Excélsior fueron registrados, y un $3.3 \%$ de estos ya no está vigente en la $22^{\text {a }}$ edición. Este porcentaje es algo mayor en la $22^{\mathrm{a}}$ edición, que acepta un $34 \%$ de los anglicismos del corpus, de entre los cuales hay un 8.8\% que no habían sido admitidos en ediciones anteriores. Estos datos pueden ser consecuencia de la reciente incorporación de estos anglicismos a la lengua, de manera que la Academia aún no ha tenido tiempo de valorar la necesidad de incorporarlos al diccionario. 
Durante las ediciones del siglo XIX se registró un número no muy elevado de anglicismos. Con respecto a la tipología de los anglicismos admitidos en las ediciones de este siglo, la mayor parte de estos estaban formados por grafías acordes a la ortografía de la lengua española por estar ya asimilados a la lengua española o bien porque a pesar de ser iguales a la voz de procedencia inglesa, sus grafías no desentonan dentro del léxico español. En cuanto a la información etimológica de estas voces, aunque en las ediciones anteriores los orígenes son más variados, la $22^{\text {a }}$ edición del diccionario acepta el origen inglés de la mayoría de los anglicismos.

Las ediciones del siglo xx admiten un número mucho mayor de anglicismos que las ediciones anteriores. En cuanto a la clasificación formal de estos, destacan los anglicismos crudos gráficamente iguales a su voz original y aunque presentan diferentes orígenes etimológicos, normalmente se hace alusión a su origen inglés. Asimismo se encontró un grupo bastante representativo de anglicismos ya asimilados a la lengua española, algunos de ellos definidos como procedentes "del inglés", aunque muchos de ellos sin marca de extranjerismo. En la mayoría de los anglicismos de apariencia parcialmente inglesa aceptados en los diccionarios académicos del siglo xx se admitía el origen inglés de las voces y los calcos léxicos eran normalmente aceptados como voces españolas.

La mayor parte de los anglicismos admitidos en las ediciones del siglo XIX y del xx siguen vigentes en la $22^{\mathrm{a}}$ edición del diccionario. Casi todos estos anglicismos han mantenido la grafía con la que fueron admitidos y se definen 
normalmente como voces procedentes "del inglés" o "voz inglesa", excepto en el caso de los anglicismos totalmente asimilados al español y los calcos léxicos en los que no hay normalmente alusión al origen foráneo, probablemente por considerarse ya vocablos totalmente españolizados.

Asimismo se encontró un número bastante elevado de anglicismos que eran de nueva incorporación, es decir, que se habían registrado por primera vez en la edición de 2001. Algunos de estos tenían una apariencia parcialmente inglesa, estaban completamente asimilados y también se encontraron varios calcos léxicos aunque como ya ocurrió durante el siglo anterior, destacó la admisión de anglicismos crudos.

A pesar del carácter normativo de la Real Academia Española y aunque el número de anglicismos extraídos del corpus que se admitieron en alguna de las ediciones de los diccionarios no es demasiado elevado, se observan dos tendencias. El número de anglicismos aceptados se va incrementando progresivamente con el paso del tiempo. Este fenómeno es más evidente en las últimas ediciones del siglo xx y en la del siglo xxI. Asimismo crece la tendencia en el diccionario de aceptar voces que contienen grafías no aceptables en la ortografía española. Mientras en las ediciones del siglo XIX primaban los anglicismos asimilados, ya en el siglo xx y aún más en el siglo xxi destaca claramente la aceptación de los anglicismos crudos que puede ser consecuencia del uso del inglés como lengua franca en la comunicación internacional que hace que cada vez sea más necesario incluir en nuestras lenguas anglicismos considerados universales. 


\section{Bibliografía}

Alcoba, Santiago (2006), "Discreción y uso. Anglicismos, DRAE y lengua periodística", Lingua Americana XIX, pp. 88-110.

Aleza Izquierdo, Milagros (2008), "Sobre la presencia de voces de origen extranjero en el $D P D$ ", en Antonio Álvarez Tejedor (coord.), Lengua viva. Estudios ofrecidos a César Hernández Alonso, Valladolid, Universidad de Valladolid y Diputación de Valladolid, pp. 255-270.

Alfaro, Ricardo (1948), "El anglicismo en el español contemporáneo", Thesaurus, IV, I, pp. 102-120.

Alvar Ezquerra, Manuel (1998), "Palabras nuevas en los periódicos de hoy", en A. Álvarez Tejedor (coord.), $L a$ lengua española a finales del milenio, Burgos, Caja de Burgos, pp. 13-44.

Azorín, Dolores (2007), "La incorporación de neologismos en los diccionarios del español del siglo xıx: criterios y realizaciones", en Mar Campos Souto, María Montserrat Muriano Rodríguez y José Ignacio Pérez Pascual (eds.), El nuevo léxico, Coruña, Servizo de Publicacións Universidade da Coruña, pp. 53-66.

Balteiro, Isabel (2011), "Prescriptivism and Descriptivism in the Treatment of Anglicisms in a series of bilingual Spanish-English Dictionaries", International Journal of Lexicography, XXIV, III, pp. 277-305.

Barcia, Pedro Luis (2005): "Tratamiento de neologismos y extranjerismos en el $D P D$ ". Presentación del Diccionario panhispánico de dudas. 
Cruz-Cabanillas, Isabel de la y Cristina Tejedor MarTÍnEZ (2012), "E-mail o correo electrónico? Anglicisms in Spanish", Revista Española de Lingüística Aplicada, 1, pp. 95-118.

(2014), "Anglicisms Everywhere! The Influence of English as a Global Language", en Globalisierung, interkulturelle Kommunikation und Sprache, Fráncfort, Peter Lang, pp. 123-132.

Degerstedt, Andrea (2013), "Guardar o no guardar, una cuestión de prestar: un estudio de neologismos y préstamos y su inclusión en el Diccionario de la Real Academia Española”, tesis inédita.

Domínguez Mejías, Elena (2002), "Los anglicismos en el diccionario de la RAE”,Panace@, III, VIII, pp. 28-33.

Garriga Escribano, Cecilio y Francesc Rodríguez (2008), "Notas al 'Diccionario manual e ilustrado de la lengua española' (RAE, 1927)", en El diccionario como puente entre las lenguas y culturas del mundo. Actas del II Congreso Internacional de Lexicografía Hispánica, pp. 96-105.

Giménez Folqués, DAvid (2010), “Introducción a los extranjerismos del diccionario panhispánico de dudas y criterios de adaptación”, en Milagros Aleza Izquierdo (coord.), Normas y usos correctos en el español actual, Valencia, Tirant lo Blanch, pp. 217-228.

Gómez Capuz, Juan (1998), El préstamo lingüístico (conceptos, problemas y métodos), Valencia, Servicio de Publicaciones de la Universitat de València. 
Gómez Capuz, Juan (2000), Anglicismos léxicos en el español coloquial, Cádiz, Servicio de Publicaciones de la Universidad de Cádiz.

Haensch, Günther y Carlos Omeñaca (2004), Los diccionarios del español en el siglo XXI, 2a edición corregida y aumentada, Salamanca, Universidad de Salamanca.

Lope Blanch, JuAn (1986), “Anglicismos en el español del suroeste de los Estados Unidos”, en Sebastian Neumeister (ed.), Actas del IX Congreso de la Asociación Internacional de Hispanistas, Fráncfort, Vervuert, pp. 131-138.

López Morales, Humberto (1987), “Anglicismos léxicos en el habla culta de San Juan de Puerto Rico", Lingüística Española Actual, IX, 2, pp. 285-303.

Lorenzo, Emilio (1987), "Anglicismos en la prensa”, en Primera reunión de Academias de la Lengua Española sobre el lenguaje y los medios de comunicación, Madrid, Real Academia Española, pp. 71-79.

- (1996), Anglicismos hispánicos, Madrid, Gredos.

Medina López, Javier (1996): El anglicismo en el español actual, Madrid, Arco-Libros.

NTLLE: Nuevo tesoro lexicográfico de la lengua española. Disponible en línea en http://buscon.rae.es-ntlle-SrvltGUILoginNtlle.

Perdiguero, Hermógenes (2003), “Innovación léxica en la prensa”, en Hermógenes Perdiguero y Antonio Álvarez (eds.), Medios de comunicación y enseñanza del español como lengua extranjera: Actas del XIV Congreso internacional de ASELE, Burgos, Servicio de Publicaciones de la Universidad de Burgos, pp. 10-31. 
Pratt, Chris (1980), El anglicismo en el español peninsular contemporáneo, Madrid, Gredos.

Real Academia Española (2001), Diccionario de la lengua española, Madrid (consultado en http://www.rae. es/rae.html).

Rodríguez González, Félix (1999), “Anglicisms in Contemporary Spanish. An Overview", Atlantis, 21, pp. 103-139.

Rodríguez Medina, María Jesús (2000), "El anglicismo en español: revisión crítica del estado de la cuestión", Philologia Hispalensis, 14, 1, pp. 99-112.

Rodríguez Segura, Delia (1999), Panorama del anglicismo en español: presencia y uso en los medios, Almería, Universidad de Almería.

Rosenblat, Ángel (1970), El castellano de España y el castellano de América. Unidad y diferenciación, Madrid, Taurus.

SÁez Godoy, Leopoldo (2005), "Anglicismos en el español de Chile", Atenea, 492, pp. 171-177.

SÁnchez Lobato, Jesús (1994), "El español en América”, en Jesús Sánchez Lobato e Isabel Santos Gargallo (eds.), Actas del Cuarto Congreso Internacional de ASELE, Madrid, SGEL, pp. 553-570.

Sánchez Martín, Francisco Javier (2011), “El trabajo de la Real Academia Española en el avance de la 23a edición del Diccionario de la lengua española: las voces inglesas", Lexis, XXXV, pp. 143-161.

Seco, Manuel (2000), "La importación léxica y la unidad del idioma: anglicismos en Chile y España", Boletín de Filología de la Universidad de Chile, 38, pp. 253-280. 
VÁzquez Amador, María (2015), “Estudio descriptivo de la influencia del inglés en la prensa mexicana del siglo XIX”, Tonos Digital. Revista Electrónica de Estudios Filológicos, 29, pp. 1-26.

Vives Coll, Antonio (1989), "Los anglicismos económicos en los DRAE de 1970 y 1984", Revista de Filología de la Universidad de la Laguna, VIII-IX, pp. 405-411.

\section{Anexo. Diccionarios consultados}

Real Academia Española, Diccionario de la lengua castellana, en que se explica el verdadero sentido de las voces, su naturaleza y calidad, con las phrases o modos de hablar, los proverbios o refranes, y otras cosas convenientes al uso de la lengua [...]. Compuesto por la Real Academia Española. Tomo primero. Que contiene las letras A.B. Madrid, Imprenta de Francisco del Hierro, 1726.

- Diccionario de la lengua castellana, en que se explica el verdadero sentido de las voces, su naturaleza y calidad, con las phrases o modos de hablar, los proverbios o refranes, y otras cosas convenientes al uso de la lengua [...]. Compuesto por la Real Academia Española. Tomo segundo. Que contiene la letra C. Madrid, Imprenta de Francisco del Hierro, 1729.

Diccionario de la lengua castellana, en que se explica el verdadero sentido de las voces, su naturaleza y calidad, con las phrases o modos de hablar, los proverbios o refranes, y otras cosas convenientes al uso de la lengua [...]. Compuesto por la Real Academia Española. Tomo tercero. Que contiene las letras D.E.F. Madrid, Imprenta de 
la Real Academia Española por la viuda de Francisco del Hierro, 1732.

Real Academia Española, Diccionario de la lengua castellana, en que se explica el verdadero sentido de las voces, su naturaleza y calidad, con las phrases o modos de hablar, los proverbios o refranes, y otras cosas convenientes al uso de la lengua [...]. Compuesto por la Real Academia Española. Tomo quarto. Que contiene las letras G.H.I.J.K.L.M.N. Madrid, Imprenta de la Real Academia Española, por los herederos de Francisco del Hierro, 1734.

_- Diccionario de la lengua castellana, en que se explica el verdadero sentido de las voces, su naturaleza y calidad, con las phrases o modos de hablar, los proverbios o refranes, y otras cosas convenientes al uso de la lengua [...]. Compuesto por la Real Academia Española. Tomo quinto. Que contiene las letras O.P.Q.R. Madrid, Imprenta de la Real Academia Española, por los herederos de Francisco del Hierro, 1737.

- Diccionario de la lengua castellana, en que se explica el verdadero sentido de las voces, su naturaleza y calidad, con las phrases o modos de hablar, los proverbios o refranes, y otras cosas convenientes al uso de la lengua [...]. Compuesto por la Real Academia Española. Tomo sexto. Que contiene las letras S.T.V.X.Y.Z. Madrid, Imprenta de la Real Academia Española, por los herederos de Francisco del Hierro, 1739.

- Diccionario de la lengua castellana compuesto por la Real Academia Española. Segunda impresión corregida y aumentada. Tomo primero. A-B. Madrid, Joachín Ibarra, 1770. 
Real Academia Española, Diccionario de la lengua castellana compuesto por la Real Academia Española, reducido a un tomo para su más fácil uso. Madrid, Joaquín Ibarra, 1780.

Diccionario de la lengua castellana compuesto por la Real Academia Española, reducido a un tomo para su más fácil uso. Segunda edición, en la qual se han colocado en los lugares correspondientes todas las voces del Suplemento, que se puso al fin de la edición del año de 1780, y se ha añadido otro nuevo suplemento de artículos correspondientes a las letras $A, B$ y C. Madrid, Joaquín Ibarra, 1783.

- Diccionario de la lengua castellana compuesto por la Real Academia Española, reducido a un tomo para su más fácil uso. Tercera edición, en la qual se han colocado en los lugares correspondientes todas las voces de los suplementos, que se pusieron al fin de las ediciones de los años de 1780 y 1783, y se han intercalado en las letras D.E. y F. nuevos artículos, de los quales se dará un suplemento separado. Madrid, Viuda de Joaquín Ibarra, 1791.

- Diccionario de la lengua castellana compuesto por la Real Academia Española, reducido a un tomo para su más fácil uso. Quarta edición. Madrid, Viuda de Ibarra, 1803.

Diccionario de la lengua castellana por la Real Academia Española. Quinta edición. Madrid, Imprenta Real, 1817.

- Diccionario de la lengua castellana por la Real Academia Española. Sexta edición. Madrid, Imprenta Nacional, 1822. 
Real Academia Española, Diccionario de la lengua castellana por la Real Academia Española. Séptima edición. Madrid, Imprenta Real, 1832.

- Diccionario de la lengua castellana por la Real Academia Española. Octava edición. Madrid, Imprenta Nacional, 1837.

- Diccionario de la lengua castellana por la Real Academia Española. Novena edición. Madrid, Imprenta de D. Francisco María Fernández, 1843.

_ Diccionario de la lengua castellana por la Real Academia Española. Décima edición. Madrid, Imprenta Nacional, 1852.

_ Diccionario de la lengua castellana por la Real Academia Española. Undécima edición. Madrid, Imprenta de Don Manuel Rivadeneyra, 1869.

— Diccionario de la lengua castellana por la Real Academia Española. Duodécima edición. Madrid, Imprenta de D. Gregorio Hernando, 1884.

— Diccionario de la lengua castellana por la Real Academia Española. Décimatercia edición. Madrid, Imprenta de los Sres. Hernando y compañía, 1899.

_ Diccionario de la lengua castellana por la Real Academia Española. Décimocuarta edición. Madrid, Imprenta de los sucesores de Hernando, 1914.

Diccionario de la lengua española. Décima quinta edición. Madrid, Calpe, 1925.

- Diccionario de la lengua española. Décima sexta edición. Madrid, Espasa-Calpe, 1936. 
Real Academia Española, Diccionario de la lengua española. Décima sexta edición. Madrid, Espasa-Calpe, Año de la Victoria [1939].

— Diccionario de la lengua española. Décimoséptima edición. Madrid, Espasa-Calpe, 1947.

- Diccionario de la lengua española. Décimoctava edición. Madrid, Espasa-Calpe, 1956.

— Diccionario de la lengua española. Décimonovena edición. Madrid, Espasa-Calpe, 1970.

— Diccionario de la lengua española. Vigésima edición. Madrid, Espasa-Calpe, 1984, 2 tomos.

_ Diccionario de la lengua española. Vigésima primera edición. Madrid, Espasa-Calpe, 1992.

— Diccionario histórico de la Lengua Española. Tomo I.A. Madrid, Imprenta de Librería y Casa Editorial Hernando, 1933

Diccionario histórico de la Lengua Española. Tomo II.-B-Cevilla. Madrid, Imprenta de Librería y Casa Editorial Hernando, 1936

_ Diccionario manual e ilustrado de la lengua española. Madrid, Espasa-Calpe, 1927.

- Diccionario manual e ilustrado de la lengua española. Segunda edición. Madrid, Espasa-Calpe, 1950.

- Diccionario manual e ilustrado de la lengua española. Tercera edición revisada. Tomo I. A-Capachero. Madrid, Espasa-Calpe, 1983.

Diccionario manual e ilustrado de la lengua española. Tercera edición revisada. Tomo II. Capacho-Divo. Madrid, Espasa-Calpe, 1983. 
Real Academia Española, Diccionario manual e ilustrado de la lengua española. Tercera edición revisada. Tomo III. Divorciado-Incógnita. Madrid, Espasa-Calpe, 1984.

- Diccionario manual e ilustrado de la lengua española. Tercera edición revisada. Tomo IV. Incógnito-Papel. Madrid, Espasa-Calpe, 1984.

- Diccionario manual e ilustrado de la lengua española. Tercera edición revisada. Tomo V. Papelamen-Sake. Madrid, Espasa-Calpe, 1985.

_ Diccionario manual e ilustrado de la lengua española. Tercera edición revisada. Tomo VI. Sal-Zuzón. Madrid, Espasa-Calpe, 1985.

- Diccionario manual e ilustrado de la lengua española. Cuarta edición revisada. Madrid, Espasa-Calpe, 1989. 
